\title{
Benzodiazepiner til personer med rusmiddelproblemer?
}

\author{
Benzodiazepiner eller benzodiazepinliknende medikamenter brukes \\ sannsynligvis for ofte til personer som har rusmiddelproblemer. \\ Midlene gir ofte effektiv lindring på kort sikt, men farmakodynamisk \\ samvirke med rusmidlene og tilvenning til bruken skaper betydelige \\ problemer i behandlingen. Utydelige - men viktige - bivirkninger blir \\ ikke tilstrekkelig forstått. Kunnskapsbasert praksis bør erstatte uklart \\ begrunnet forskrivning.
}

Se også kunnskapsprøve på www.tidsskriftet.no/quiz

\author{
Helge Waal \\ helge.waal@medisin.uio.no \\ Jørgen G. Bramness \\ Senter for rus- og avhengighetsforskning \\ Universitetet i Oslo \\ Kirkeveien 166 \\ 0407 Oslo
}

Benzodiazepin- og benzodiazepinliknende preparater benyttes $\mathrm{i}$ behandlingen av angstsymptomer, angstlidelser og søvnvansker, men også av muskelstramninger, krampetilstander og annet. Preparatene har en hurtig innsettende og pålitelig effekt og er lite toksiske. Allerede i 1966, seks år etter lanseringen på verdensmarkedet, ble det beskrevet et tilfelle av benzodiazepinavhengighet (1). Toleranseutvikling gjør at den terapeutiske effekten kan avta relativt raskt. Ved seponering vil symptomer kunne komme tilbake, ofte med tillegg av abstinensfenomener. Bruken bør derfor begrenses til korte perioder. Langtidsforskrivning frarådes, men likevel er langtidsbruk vanlig. Dette kalles ofte lavdoseavhengighet eller kvasiterapeutisk langtidsbruk (2). Slike brukere har ofte små sosiale problemer og liten grad av ruspreget atferd. Problemene er i første rekke knyttet til svekket kognisjon, svekket psykomotorisk kontroll med blant annet falltendens, økt forekomst at trafikkulykker og andre ulykker, søvnproblemer tross sovemiddelbruk og tendens til dysfori og mistrivsel (1). Slike pasienter bør motiveres til langsom nedtrapping (3). Når dette mislykkes, fortsetter noen $\mathrm{i}$ langtidsbehandling uten klart formål.

Benzodiazepinene kan også brukes som rusmidler. Benzodiazepiner forsterker farmakodynamisk de dempende og rusgivende effektene av andre rusmidler (1). Oftest blir de derfor brukt sammen med andre rusmidler, sjelden som det eneste. Midlene demper også angst og stressopplevelser, som er bivirkninger ved bruk av sentralstimulerende midler. Bruken inngår derfor ofte i slikt misbruk. Legemiddelassistert rehabilitering (LAR) tar sikte på å stabilisere opioidavhengige pasienter på et høyt nivå av langtidsvirkende opiater, slik at pasientene ikke har rustrang, men er uten psykomotorisk dempning. Benzodiazepiner til disse pasientene kan føre til ruseffekt og psykomotorisk og kognitiv svekkelse. Dette er uheldig for aktiv rehabilitering. Overdoser mens man går i denne type behandling har nesten uten unntak bakgrunn i samtidig bruk av benzodiazepiner eller alkohol. Overdosefaren ved heroinbruk er også nært knyttet til samtidig benzodiazepinbruk (4).

Benzodiazepinpreparater brukt til rusformål er delvis ført inn og omsatt illegalt og delvis forskrevet av leger. Innen Legemiddelassistert rehabilitering utsettes behandlere for et betydelig press både fra pasienter og leger om å akseptere forskrivning av benzodiazepiner. På denne bakgrunn er det viktig å undersøke om benzodiazepiner har noen plass ved behandling av pasienter med rusmiddelproblemer og i så tilfelle på hvilke indikasjoner.

\section{Materiale og metode}

Artikkelen bygger på forfatternes erfaringer og en systematisk kunnskapsoppsummering fra Kunnskapssenteret fra 2007 (5). I tillegg er det søkt i oppsummeringer fra Cochranedatabasen og Nice-publikasjoner.

\section{Farmakologi}

De relevante preparatene er alle agonister ved $\gamma$-aminosmørsyre $\left(\mathrm{GABA}_{\mathrm{A}}\right)$-reseptoren og øker effekten av GABA, som er den viktigste dempende nevrotransmittoren i sentralnervesystemet (fig 1).
Sju benzodiazepiner har markedsføringstillatelse i Norge. Tre av disse har hovedindikasjon angstlidelser (diazepam, oksazepam og alprazolam), tre har hovedindikasjon søvn (nitrazepam, flunitrazepam og midazolam), mens den siste har hovedindikasjon epilepsi (klonazepam). De siste 15 årene har to benzodiazepinliknende sovemidler blitt markedsført i Norge (zopiklon og zaleplon). Det brukes også andre benzodiazepiner på registreringsfritak. Generiske navn, salgsnavn, dosering og farmakokinetiske egenskaper finnes i tabell 1.

Det er to hovedforskjeller mellom benzodiazepinene. Noen vil ha raskere tilslag og mer kortvarig effekt. Dette er delvis (men bare delvis) relatert til terminal halveringstid (tab 1). Ulik indikasjon medfører ulik dosering, slik at definerte døgndoser (DDD) ikke kan sammenliknes på tvers av medikamentene. Det er dessuten betydelig forskjell i potens. $1 \mathrm{mg}$ flunitrazepam, $0,5-1 \mathrm{mg}$ alprazolam og $0,5 \mathrm{mg}$ klonazepam er ekvipotent med $10 \mathrm{mg}$ diazepam (1). Høypotente midler med raskt innsettende effekt vil gi større rusvirkning. Disse stoffene er derfor ettertraktet som rusmiddel. Den rusgivende effekten er først og fremst knyttet til et eget segment av $\mathrm{GABA}_{\mathrm{A}}$-reseptorkomplekset som påvirkes av alle benzodiazepinene og av de benzodiazepinliknende sedativene. Medikamenter som virker ved $\mathrm{GABA}_{\mathrm{B}}{ }^{-}$ reseptoren har ikke slik virkning.

\section{Nevroadaptasjon, abstinens og avhengighet}

Rusvirkning og avhengighetsutvikling studeres dels i dyreforsøk og dels i eksperimentelle og kliniske studier av humane populasjoner (2). Tidlige studier viste liten avhengighetstendens i dyreforsøk. Friske ikke-brukere opplever dessuten virkningen

\section{Hovedbudskap}

- Det er ikke dokumentert terapeutisk effekt av benzodiazepiner til personer med rusmiddelproblemer

- Benzodiazepiner forverrer avhengighetsproblemer hos rusmisbrukere og gir redusert psykomotorisk og kognitiv funksjon

- Forskningen på området er mangelfull. Rusmiddelbruk er eksklusjonskriterium i de fleste studier 
Figur $1 G A B A_{A}$-reseptoren er en pentamerisk $\mathrm{Cl}^{-}$-kanal, som oftest plassert postsynaptisk. De fem subenhetene er som oftest $2 \alpha$-, $2 \beta$-og $1 \gamma$-subenheter. De ulike subenhetene vil finnes i ulike varianter. Hvilken type $\alpha$-subenhet et medikament binder seg til, vil i noen grad avgjøre dets misbrukspotensial. Mens etanol og barbiturater åpner ionekanalen uten at GABA er til stede, vil benzodiazepiner og z-hypnotika være avhengig av tilstedeværende GABA. Dette er noe av forklaringen på hvorfor man når en takeffekt ved høye doser benzodiazepiner

av benzodiazepiner som lite attraktiv. Imidlertid vil dyr og mennesker som bruker midlet gjentatt, utvikle nevroadapsjon. Fortsatt bruk blir da attraktivt, og opphør gir abstinens. Abstinensen kommer raskere ved midler med kort halveringstid.

\section{Benzodiazepiner ved ruslidelser}

Det er derfor gode grunner til å advare mot å forskrive benzodiazepiner til rusmiddelbrukere. Likevel viser det seg at personer som har et misbruksproblem oftere får forskrevet benzodiazepiner enn personer som ikke har det (6). Det forverrer deres utsikt til forbedring (7). Dette gjelder også pasienter innen legemiddelassistert rehabilitering (8).

Nasjonalt kunnskapssenter for helsetjenesten fant $i$ en rapport om bruk av benzodiazepiner til personer med rusmiddellidelser at studiene i klinisk benzodiazepinforskning gjennomgående hadde rusmiddelbruk som eksklusjonskriterium (1). Det ble ikke funnet studier som dokumenterte effekt av benzodiazepiner, heller ikke for de tradisjonelle indikasjonene (angst, søvnproblemer eller epilepsi) hos personer med rusmiddelproblemer. I oppsummeringen fant man kun én systematisk oversikt, 33 randomiserte kontrollerte studier og fire observasjonsstudier. Kun to randomiserte kontrollerte studier omhandlet misbrukere av illegale rusmidler. De andre studiene omhandlet kroniske brukere av benzodiazepiner (14 studier), friske frivillige med en fortid med bruk av rusmidler (12 studier) og personer med alkoholmisbruk (seks studier).

Studiene bekreftet at benzodiazepiner fører til rusopplevelser og kan gi avhengighet hos rusmisbrukere og kroniske brukere av benzodiazepiner. For eksempel fant Griffiths og medarbeidere at friske frivillige med for-

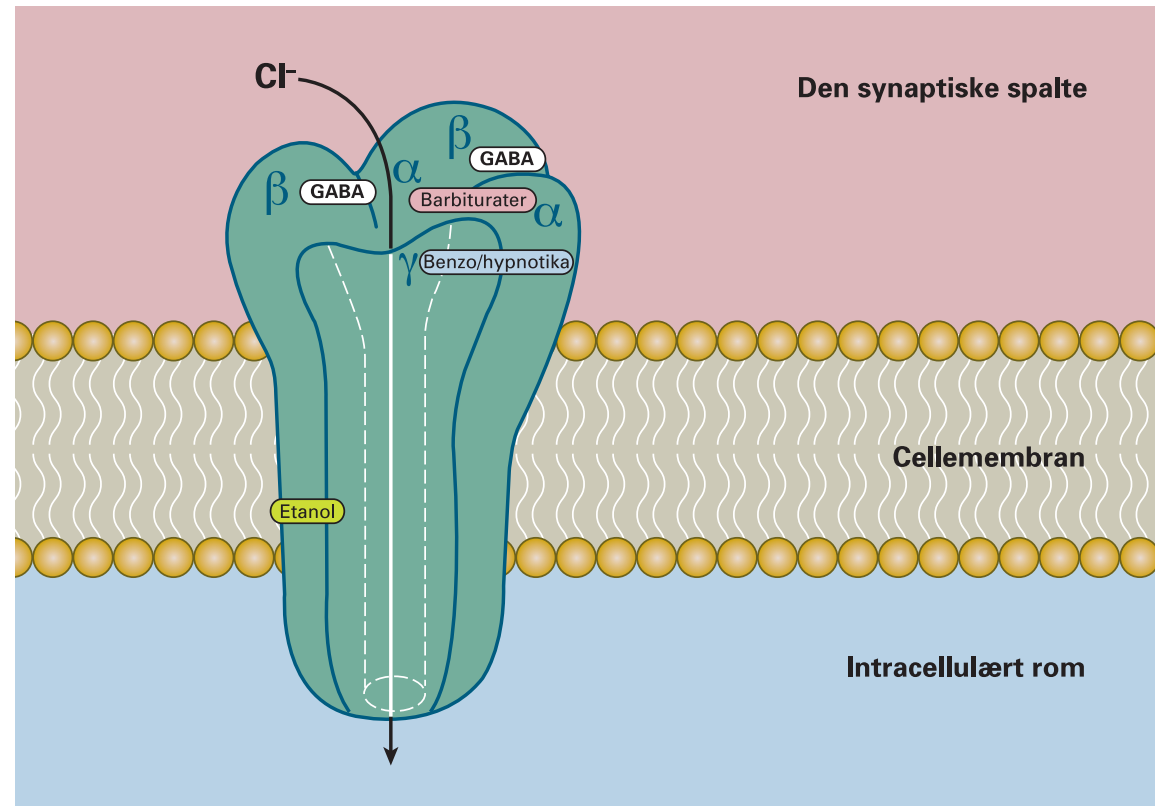

tid som rusmiddelbrukere fikk rusopplevelse ved bruk av oksazepam og diazepam, men ikke ved placebo (9). Mintzer \& Griffiths fant det samme ved undersøkelse av flunitra- zepam og triazolam. Begge studiene viste også observerbare atferdsendringer (10). Benzodiazepiner ga redusert psykomotorisk og kognitiv funksjon hos kroniske brukere og
Tabell 1 Benzodiazepiner og benzodiazepinlignende medikamenter som ble solgt i Norge i 2008 med definert døgndose (DDD), salgsnavn og terminal eliminasjonshalveringstid $\left(\mathrm{T}_{1 / 2}\right)$

\begin{tabular}{|c|c|c|c|c|}
\hline & & $\mathrm{DDD}^{1}$ & $\begin{array}{l}\text { Salgsnavn } \\
\text { i Norge }\end{array}$ & Halveringstid \\
\hline \multicolumn{5}{|l|}{ Anxiolytika } \\
\hline & Diazepam & 10 mg & $\begin{array}{l}\text { Stesolid, Valium, } \\
\text { Vival }\end{array}$ & $15-60$ timer $^{2}$ \\
\hline & Klordiazepoksid & $30 \mathrm{mg}$ & 3 & 5-30 timer \\
\hline & Oksazepam & $50 \mathrm{mg}$ & Alopam, Sobril & $8-10$ timer \\
\hline & Lorazepam & $2,5 \mathrm{mg}$ & 3 & 10-12 timer \\
\hline & Bromazepam & $10 \mathrm{mg}$ & 3 & 8-20 timer \\
\hline & Klobazam & $20 \mathrm{mg}$ & 3 & 10-30 timer \\
\hline & Alprazolam & $1 \mathrm{mg}$ & Xanor & 10-12 timer \\
\hline \multicolumn{5}{|l|}{ Hypnotika } \\
\hline & Flurazepam & $30 \mathrm{mg}$ & 3 & 47-100 timer \\
\hline & Nitrazepam & $5 \mathrm{mg}$ & $\begin{array}{l}\text { Apodorm, } \\
\text { Mogadon }\end{array}$ & 18-25 timer \\
\hline & Flunitrazepam & $1 \mathrm{mg}$ & Flunipam & 20-30 timer \\
\hline & Triazolam & $0,25 \mathrm{mg}$ & 3 & $3-4$ timer \\
\hline & Midazolam & $15 \mathrm{mg}$ & Versed 4 & $2-5$ timer \\
\hline & Zopiklon & $7,5 \mathrm{mg}$ & $\begin{array}{l}\text { Imovane, } \\
\text { Zopiclone }\end{array}$ & $4-5$ timer \\
\hline & Zolpidem & 10 mg & Stilnoct, Zolpidem & 2 timer \\
\hline \multicolumn{5}{|l|}{ Antiepileptika } \\
\hline & Klonazepam & $8 \mathrm{mg}$ & Rivotril & $18-50$ timer \\
\hline
\end{tabular}

1 DDD gir ikke ekvipotens av doser på tvers av indikasjon. 1 DDD for hypnotika er 25-50\% av 1 DDD for anxiolytika, mens 1 DDD for antiepileptika er 4-8 ganger 1 DDD for anxiolytika

${ }^{2}$ Halveringstid $ø$ ker med alder. Diazepam har aktive metabolitter med lengre halveringstid

${ }^{3}$ Bare på registreringsfritak

${ }_{4}^{4}$ Bare til intravenøs injeksjon, peroralt på registreringsfritak 
rusmisbrukere (11). Bruken ga dysforiske reaksjoner og økt negativitet og fiendtlighet. For denne pasientgruppen finnes det altså ikke dokumentasjon for forsvarlighet eller nytteeffekt på psykiske lidelser.

Ingen studier anbefaler klonazepam som antiepileptisk middel for rusmiddelbrukere (1). Klonazepam brukes lite i behandling av epilepsi og er aldri førstevalg. Det er dessuten ettertraktet som rusmiddel.

\section{Abstinensbehandling}

Vi skiller her mellom delirium og abstinensreaksjoner. Forebygging og behandling av delirium tremens er nylig omtalt i denne spalten (12). Likeledes er benzodiazepiners plass $\mathrm{i}$ behandlingen av opioidabstinens nylig omtalt (13).

Kunnskapssenterets oppsummering viste at benzodiazepiner reduserer symptomer knyttet til alkoholabstinens, men dette kan oppnås like bra med midler uten misbrukspotensial, slik som karbamazepin og valproat (14). Dette gjelder både subjektivt ubehag og tendens til abstinenskramper. Enkelte har funnet noe større gjennomføringsgrad ved bruk av benzodiazepiner, men i disse studiene så man også større tilbakefallstendens. Benzodiazepiner reduserer imidlertid deliriumfaren. Dette er mest aktuelt dersom det er sterke abstinensreaksjoner. Indikasjonen er utvilsom i behandlingen av delirium (12)

Det anbefales ofte å trappe ned benzodiazepiner over flere måneder (15), støttet av andre psykososiale tiltak (16). Studiene som viste dette, var imidlertid uten unntak gjort blant personer uten andre rusmiddelproblemer. Pasienter med lavdoseavhengighet og med god sosial funksjon, vil antakelig få mindre problemer ved langsom nedtrapping over 1-3 måneder. Ved blandingsmisbruk med skiftende doseringer, også høye, viste ingen studier fordeler med langsom nedtrapping. Nedtrappingen kan da gjennomføres i løpet av tre uker med støtte av antiepileptiske midler og dempende antihistamin. Noen studier har vist nytte av flumazenil (benzodiazepinantagonist), men siden preparatet er injektabelt med kort halveringstid vil behovet for hyppige injeksjoner gjør nytten tvilsom. Lenge etter nedtrapping vil pa- sientene ha nedsatt stresstoleranse, antakelig knyttet til nevroadaptasjon. Få medikamenter har effekt for dette. Det er en viss forskningsmessig støtte for at baklofen (17) og muligens pregabalin (18) kan være til hjelp i en slik situasjon.

\section{Konklusjon}

Det finnes ikke dokumentert terapeutisk effekt av benzodiazepiner hos personer med rusmiddelproblemer. Derimot finnes det kunnskapsgrunnlag for negative effekter. Benzodiazepiner har i seg selv et rus- og avhengighetspotensial og forvansker behandling av slike problemer. Benzodiazepiner gir redusert psykomotorisk og kognitiv funksjon hos rusmisbrukere og kroniske brukere av benzodiazepiner. Disse ulempene er minst ved bruk av oksazepam og tilnærmet like for de øvrige benzodiazepinene.

For de andre GABAerge midlene nevnt $\mathrm{i}$ tabell 1 er dokumentasjonen enda mindre. Muligens er misbrukspotensial for nyere hypnotika mindre enn for de gamle, men dette er ikke endelig avgjort (19).

Sparsomt kunnskapsgrunnlag kan skyldes både manglende effekt og manglende forskning. Det er likevel grunn til å advare mot å forskrive benzodiazepiner og benzodiazepinliknende medikamenter til personer som har en misbrukshistorie. Det advares spesielt mot forskrivning til pasienter i legemiddelassistert rehabilitering. Hvis man må bruke et benzodiazepin, anbefales det å bruke et av det minst forsterkende medikamentene, som f.eks. oksazepam $(9,20)$. Ofte vil man komme like langt eller lenger med å bruke SSRI-preparater alene eller sammen med et sederende antihistamin som hydroksyzin eller antidepressiver som mirtazapin.

Oppgitte interessekonflikter: Ingen

\section{Litteratur}

1. Krzyzowski J, Michniewicz M. Case of librium addiction. Neurol Neurochir Psychiatr Pol 1966; 16: $195-6$.

2. Griffiths RR, Weerts EM. Benzodiazepine selfadministration in humans and laboratory animals - implications for problems of long-term use and abuse. Psychopharmacology 1997; 134: 1-37.

3. Mouland G. Praktiske råd om nedtrapping av benzodiazepiner. Tidsskr Nor Lægeforen 2001; 121 : $2394-5$.
4. Dietze P, Jolley D, Fry $C$ et al. Transient changes in behaviour lead to heroin overdose: results from a case-crossover study of non-fatal overdose. Addiction 2005: 100: 636-42.

5. Nilsen E. Bachs L, Bjørner T et al. Benzodiazepiner $\mathrm{i}$ behandling av personer med rusmiddelproblemer. Oslo: Kunnskapssenteret, 2007.

6. Clark RE, Xie HG, Brunette MF. Benzodiazepine prescription practices and substance abuse in persons with severe mental illness. J Clin Psychiatry 2004: 65: 151-5

7. Brunette MF, Noordsy DL, Xie H et al. Benzodiazepine use and abuse among patients with severe mental illness and co-occurring substance use disorder. Psychiatr Serv 2003; 54: 1395-401.

8. Bramness JG, Kornor H. Benzodiazepine prescrip tion for patients in opioid maintenance treatment in Norway. Drug Alcohol Depend 2007; 90: 203-9.

9. Griffiths RR, McLeod DR, Bigelow GE et al. Comparison of diazepam and oxazepam: preference, liking and extent of abuse. J Pharmacol Exp Ther 1984; 229: $501-8$

10. Mintzer MZ, Griffiths RR. Flunitrazepam and triazolam: a comparison of behavioral effects and abuse liability. Drug Alcohol Depend 1998; 53 49-66.

11. Curran HV, Collins R, Fletcher $S$ et al. Older adults and withdrawal from benzodiazepine hypnotics in general practice: effects on cognitive function, sleep, mood and quality of life. Psychol Med 2003; 33: $1223-37$

12. Helland A, Skjøtskift S. Medikamentell behandling av alkoholabstinens. Tidsskr Nor Legeforen 2008. 128: 1182-4

13. Shaygani S, Waal H. Behandling av opioid abstinens. Tidsskr Nor Legeforen 2009; 129: 114-5.

14. Ntais C. Pakos E, Kyzas P. Benzodiazepines for alcohol withdrawal. Cochrane Database Syst Rev 2005; nr. 3: CD005063.

15. Ashton H. Guidelines for the rational use of benzodiazepines. When and what to use. Drugs 1994; 48: 25-40.

16. Parr JM, Kavanagh DJ, Cahill L et al. Effectiveness of current treatment approaches for benzodiazepine discontinuation: a meta-analysis. Addiction 2009: 104: 13-24.

17. Cousins MS, Roberts DC, de Wit H. GABA(B) receptor agonists for the treatment of drug addiction: a review of recent findings. Drug Alcohol Depend 2002; 65: 209-20.

18. Chalabianloo F, Schjott J. Pregabalin og misbrukspotensial. Tidsskr Nor Legeforen 2009; 129 $186-7$

19. Hajak G, Müller WE, Wittchen HU et al. Abuse and dependence potential for the non-benzodiazepine hypnotics zolpidem and zopiclone: a review of case-reports and epidemiological data. Addiction 2003; 98: $1371-8$

20. Bergman U, Griffiths RR. Relative abuse of diazepam and oxazepam: prescription forgeries and theft/loss reports in Sweden. Drug Alcohol Depend 1986; 16: 293-301.

Manuskriptet ble mottatt 27.5. 2009 og godkjent 14.1. 2010. Medisinsk redaktør Anne Kveim Lie. 